\author{
Robert Kantor
}

\title{
PRZEPISY AUSTRIACKIEGO PRAWA KOŚCIELNEGO W SPRAWACH ZAKONNYCH OD CZASÓW CESARZOWEJ MARII TERESY DO KONKORDATU Z 1855 ROKU
}

Od początku istnienia Kościoła wielu wiernych starało się, wypełniając rady ewangeliczne, dążyć do doskonałości. Taki był początek zakonów. Ustawodawstwo justyniańskie, uważając zakony za instytucje ważne dla wiary i państwa, otaczało je opieką prawną, a zakonom i zakonnikom nadawało liczne przywileje. Tak np. klasztor nie mógł powstać, dopóki biskup „nie wzniósł rąk do nieba” i nie poświęcił miejsca. Nie można było przywdziać sukni zakonnej dopóki kandydat nie odbył trzyletniej próby. Zakonnicy prawem państwowym byli zobowiązani do wspólnego życia. Ponadto prawo państwowe normowało sposób wyboru przełożonych i skutki wystąpienia $\mathrm{z}$ zakonu ${ }^{1}$. W X w. nastąpił zwrot w życiu zakonnym, który

Ks. DR HAB. ROBERT KANTOR - Katedra Teologii Praktycznej i Prawa Kanonicznego, Wydział Teologiczny, Sekcja w Tarnowie Uniwersytetu Papieskiego Jana Pawła II w Krakowie; e-mail: kanclerz@diecezja.tarnow.pl; https://orcid.org/0000-00028599-7705

1 „Conversationis monachalis vita sic est honesta sic commendare novit Deo ad hoc venientem hominem, ut omnes quidem humanam eius maculam detergat, purum autem declaret ac rationabili naturae decentem et plurima secundum mentem operantem et humanis cogitationibus celsiorem. Si quis igitur futurus est monachus perfectus, indigent et divinorum eloquioram eruditione et conversationis integritate, ut tanta dingus factus sit mutatione. Credimus igitur et nos explanare, quod agendum est ab eis, et decretatores eos verso ad sacram viam constituere et ita nobis intention praesentis est legis, ut post illa quae de Sanctissimis Episcopis sancivimus et quae de reverendissimus Clericis disposuimus neque quod monachicum, extra quod competit relinquam”. Justiniani, V. 5, de monachis, cyt. za: Bartoszewski 1893, 3. 
trwał aż do reformacji i odznaczał się nadmierną ilością zakonów, klasztorów, mnichów i mniszek. Okres ten charakteryzował się także tym, iż oprócz zasług na polu nauki, krzewienia chrześcijaństwa, przyczynił się do upadku moralności i prawdziwej pobożności. Kanony soborów zwracały uwagę na pomnażające się bogactwo klasztorów, które tłumiły miłosierdzie i roztropność. Owo zepsucie życia zakonnego i konieczność jego reformy zauważył Sobór Trydencki (1545-1563), który w tej materii wydał 22 rozdziały na dwudziestej piątej sesji $^{2}$. Postanowienia soborowe - mało

${ }^{2}$ I. Regulares omnes ad regulae, quam profesi sunt praescriptum vitam instituant: id ut fiat superiores sedulo curent; II. Proprietas regularibus omnio prohibetur; III. Omnia monasteria quae hic non prohibentur, possunt possidere bona immobilia; numerus personarum in illis pro modo facultatum aut eleemosynarum constituendus; nulla sine licentia episcopi erigenda; IV. Regularis sine superioris licentia nec se obsequio alterius loci aut personae subiiciat, nec a conventu recedat; absentes studiorum causa in conventibus habitent; V. Claustrae monialium, praescritum quae extra urbem agunt, providetur; VI. In electione quoruncunquae superiorum eligi debere per vota secreta; VII. Quae et quomodo abbatissae et quocumquae nomine praefectae eligendae; duobus monasteriis nulla praeficiatur; VIII. Regimen monasteriorum non habentium ordinaries regulares visitatores, quomodo instituendum; IX. Monasteria monialium immediate subiecta sedi apostolicae ab episcopo regantur, alia vero a deputatis in capitulis generalibus vel aliis regularibus; X. Moniales unoquoquae mense confiteantur; de confessario extraordinario iis ab episcopis provideatur; apud illas extra publicam ecclessiam eucharistia non conservetur; XI. In monasteriis quibus imminent cura personarum saecularium, praeter eas quae sunt de illorum familia, visitet episcopus, et eidem curae preficiendas examinet, certis exceptis; XII. Conformentur regulares saecularibus in observatione censurarum episcopalium et festorum diocesis; XIII. Controversias de praecedentia e vestigio componat episcopus. Exempti non in strictiori clausura viventes ad supplicationis publicas accedere compellantur; XIV. Regulari publice deliquenti poena a quo irroganda; XV. Professio non fiat nisi anno probationis exacto et decimo sexto aetatis complete; XVI. Rennuntiatio aut obligation facta ante duos menses proximos proffesioni sit nulla. Finita probatione, novitii aut profiteantur, aut eiiciantur. In pio societatis Jesu instituto nihil innovetur. Cavetur ne quid ex bonis novitii monasterio tribuatur ante professionem; XVII. Puella maior duodecim annis, si habitum regularem suscipere voluerit exploretur ab ordinario; iterum ante professionem; XVIII. Ne quis praeterquam in casibus a iure expressis, cogat mulierem ad igrediendum monasterium, aut ingredi volentem prohibeat: paenitentium seu convertitarum constitutions serventur; XIX. Quomodo in causis deficientium a religion procedendum; $\mathrm{XX}$. Superiores ordinum episcopis non subiecti inferior monasteria visitant ac corrigant, etiam commendata; XXI. Monasteria regularibus conferantur; ordinum capita nemini in postrenum commendentur; XXII. Praedicta de reformation regularium nulla mora interposita observentur. Sanctum Concilium Tridentino, Decretum de regularibus et monialibus (sessio XXV/A) (03.12.1563), w: Sacrorum Conciliorum nova, et amplissima collectio, t. XXXIII: Ab anno MDXLV ad annum MDLXV, red. J.D. Mansi, Parisiis 1902, kol. 172-81; tekst polski w: Dokumenty Soborów Powszechnych. Tekst 
uwzględniane przez same zakony - nie były w stanie już więcej wpłynąć na wolę panujących świeckich. Nie były także w stanie zażegnać niebezpieczeństwa polityki antyzakonnej władców, której kulminacja w Austrii przypadła na rozporządzenia cesarza Józefa II i rewolucji francuskiej ${ }^{3}$.

Józefinizm próbował stworzyć autonomiczny Kościół narodowy, połączony z Rzymem, ale jednocześnie całkowicie podporządkowany aktualnie panującemu władcy. W realizację tego celu wpisywał się nurt antyzakonny w polityce kościelnej Austrii zapoczątkowany za panowania cesarzowej Marii Teresy (1740-1780), a później rozwijany przez jej następców: cesarza Józefa II (1780-1790), Leopolda II (1790-1792), Franciszka II (1792-1835), Ferdynanda I (1835-1848).

Cel niniejszego artykułu stanowi analiza ustawodawstwa austriackiego od czasów panowania cesarzowej Marii Teresy do konkordatu z dnia 18 sierpnia 1855 r. w sprawach dotyczących kwestii zakonnych. Ustawodawstwo zostanie przedstawione chronologicznie.

\section{DEKRETY CESARZOWEJ MARII TERESY}

Paradoksem rządów cesarzowej Marii Teresy była jej osobista religijność ${ }^{4}$ i jednocześnie 164 wydane przez nią rozporządzenia $\mathrm{w}$ sprawach Kościoła, znacznie dezorganizujące życie kościelne na terenie monarchii [Krętosz 1996, 43].

Maria Teresa akceptowała poglądy mające na celu poddanie spraw Kościoła państwu. Panujący żądali cedowania im przez Rzym prawa obsadzania wyższych stanowisk kościelnych, kontroli wydawanych przez papieża zarządzeń, dokumentów i ograniczania jurysdykcji nuncjuszy. Kościół winien być samorządny w obrębie kraju, rządzony przez miejscowych biskupów, lecz pozostawać pod nadzorem władz świeckich. W myśl tych poglądów, władca miałby także prawo kontroli spraw finansowych Kościoła, łącznie z opodatkowaniem go, sekularyzowaniem dóbr kościelnych i ich

taciński i polski, t. IV: (1511-1870). Lateran V. Trydent. Watykan I, układ i oprac. A. Baron, H. Pietras, Wydawnictwo WAM, Kraków 2004, s. 784-808.

${ }^{3} \mathrm{Na}$ temat ideologicznego podłoża kasat w XVIII w. zob. Bruździński 2014, 142-43.

${ }^{4}$ Cesarzowa Maria Teresa bywała codziennie na dwóch Mszach św. Miała ułożyć modlitewnik. Ustanowione przez nią komisje czuwały nad czystością obyczajów. Historycy opowiadają nawet, że jej ministrowie, a wśród nich Kaunitz, musieli przed cesarzową wykazywać poświadczenia odbytych spowiedzi [Bartoszewski 1893, 26]. 
konfiskatami. Maria Teresa religię katolicką uznawała za ostoję porządku i moralności. Sama cesarzowa miała jej być w tym pomocna, ale jednocześnie głoszący ją Kościół, w imię suwerenności państwa, winien zostać uwolniony od nadzoru władzy obcej. Za taką uznano Rzym oraz biskupów rezydujących poza granicami państwa. Maria Teresa zakazała więc władzom kościelnym monarchii bezpośredniego kontaktowania się z Rzymem. Można to było robić wyłącznie za pośrednictwem Kancelarii Dworu [Góralski 1995, 202-203].

Ostrze reform kościelnych dotknęło także życie zakonne. Maria Teresa hołdowała poglądom, że dobrobyt państwa wywodzi się z pracy, podczas której czas i potencjał ludzi nie mogą być marnowane. Cesarzową drażniła duża liczba zasobnych klasztorów z masą "nieproduktywnych mnichów” [tamże, 204]. Zapoczątkowała reformę zakonów wydając szereg unormowań prawnych (rozporządzeń i dekretów):

1) Celem zapobieżenia wzrostu liczby duchowieństwa klasztornego cesarzowa rozporządzeniem z dnia 27 marca $1767 \mathrm{r}$. zabroniła przyjmowania do zakonu kandydatów bez wcześniejszego zezwolenia rządu. Przed udzieleniem takiej zgody specjalna komisja miała zbadać, czy przyjęcie nowych członków będzie korzystne czy też zgubne dla klasztoru [Bartoszewski 1893, 26].

2) Patent z dnia 31 sierpnia 1771 r. zniósł więzienia zakonne, ograniczając tym samym władzę przełożonego do zamykania zakonników [tamże, 27].

3) Rozporządzeniem z dnia 4 września 1771 r. zakazano wszystkim zakonnikom - bez wyjątku exempti vel non exempti ordinis - wywożenia pieniędzy za granicę pod jakimkolwiek pozorem oraz wystawiania weksli płatnych za granicą. Przekroczenie tego zakazu karano konfiskatą odnośnej sumy pieniężnej, a nawet zniesieniem zakonu [tamże, 28].

4) W środowisku kościelnym Lombardii zrodził się projekt reformy klasztorów, który został przedstawiony na dworze wiedeńskim we wrześniu 1772 r. i uzyskał aprobatę cesarzowej stając się urzędową wytyczną działania. Duchowieństwo Lombardii zaproponowało, aby zaprowadzić w klasztorach ściślejszą „obserwancję”, skłonić zakonników do bardziej użytecznego działania polegającego m.in. na prowadzeniu szkół i szerzeniu oświaty. Postulowano skasowanie małych domów, niewystarczająco obsadzonych, co przyniosłoby - zdaniem projektodawców - korzyści samym zakonom, diecezjom, fundacjom pobożnym, gdyż pieniądze uzyskane ze sprzedaży majątków zakonnych mogłyby zostać przeznaczone na utrzyma- 
nie dostatniejszego życia klasztorów większych oraz na poprawę uposażenia parafii i innych instytucji. Praktyczne wskazówki owego projektu można zamknąć w następujących punktach: a) reformowaniem życia zakonnego powinny zająć się władze państwowe; b) zlikwidować należy małe domy zakonne, gdyż jest niemożliwe zachowanie w nich „obserwancji”; c) ustalić należy dopuszczalny limit („liczbę kanoniczną”) zakonników w pozostałych domach zakonnych; d) duchowieństwo zakonne winno się kierować do sławnych uczelni państwowych, aby tam zyskało wykształcenie i służyło następnie w szkolnictwie; e) część dochodów z kasaty należy przeznaczyć na poprawę sytuacji materialnej ubogich proboszczów [Chotkowski 1909, 93-96].

5) W 1774 r. cesarzowa Maria Teresa zaaprobowała bullę papieża Klemensa XIV Dominus ac redemptor noster i zniosła zakon jezuitów. Na mocy porozumienia ze Stolicą Apostolską fundusze jezuickie miały być przejęte przez władze austriackie i zużytkowane na potrzeby religijne. Cała akcja rozpoczęła się od instrukcji wysłanej przez kanclerza Kaunitza do Lwowa, która wraz $\mathrm{z}$ dołączonym formularzem miała być podstawą przeprowadzenia kasaty. Nakazano ustanowienie dla każdego kolegium osobnej komisji kasacyjnej i równoczesne rozpoczęcie czynności, co miało zapobiec wcześniejszym ostrzeżeniom przed kasatą. Dla każdego domu ustanowiono także kuratora, który miał go przejąć w posiadanie. Na początku robiono inwentarz, należało zabezpieczyć kasę i odesłać ją do banku. Przejęto w ten sposób sporą sumę gotówki jezuickiej. Część naczyń liturgicznych wydzielono do służby Bożej dla kapłana sprawującego czynności liturgiczne, resztę trzeba było zabezpieczyć. W kasacie brał udział komisarz biskupi, którego rola ograniczała się jedynie do przedstawienia breve papieskiego i wezwania do posłuszeństwa papieżowi i władzom rządowym. Resztę dopełniał komisarz świecki, który oświadczał zakonnikom, iż państwo przejmuje cały ich majątek. Po zakończeniu formalności nakazywano jezuitom natychmiast opuszczać domy i przebrać się w szaty duchownych świeckich, na co otrzymywali po 50 florenów. W dalszej kolejności następowało zatrudnienie zakonników w szkolnictwie lub duszpasterstwie, ale za zgodą rządu (w Galicji). Dekretem z dnia 5 sierpnia $1774 \mathrm{r}$. cesarzowa zgodziła się na zatrudnienie eks-jezuitów jako duszpasterzy, jednak po złożeniu przez nich specjalnego egzaminu [Wysocki 1979, 265].

6) Dnia 2 września 1774 r. Nadworna Komisja Nauk na polecenie cesarzowej poleciła gubernium lwowskiemu, aby nakazało zakonnym lektorom 
wykładać na podstawie przepisanych podręczników i stosować się do zawartych w nich zasad. Nie dowierzając nauczycielom zakonnym w następnym roku nakazano, aby w celu ujednolicenia studiów teologicznych w zakonach klerycy pobierali nauki w stolicy kraju, czyli we Lwowie. Z racji, iż każdy zakon miał we Lwowie swój główny klasztor, powinno być w nim założone studium teologiczne i do niego wszystkie zakony były zobowiązane posyłać kleryków. Zobowiązano też nauczycieli teologii do zdawania egzaminów na uniwersytecie lub w liceum. Przymus egzaminów rządowych rozciągnięto na wszystkich kleryków. Przed święceniami należało złożyć egzamin z prawa publicznego i kościelnego. Chodziło o to, by wykładano tezy kanonisty Józefa Riegera. W tym celu były przeprowadzane kontrole, czy profesorowie wykładają według przepisanego podręcznika oraz czy każdy klasztor zakupił odpowiednią ilość książek [tamże, 263].

7) Dekret cesarzowej z dnia 13 września 1774 r. dotyczył wieku zakonnej profesji. Maria Teresa ustaliła wiek 24 lat na przyjęcie profesji. Osoby, które przyjęłyby profesję zakonną przed 24 rokiem życia były narażone na surowe kary, a nawet na zniesienie zakonu ${ }^{5}$.

Cesarzowa Maria Teresa podkreślała nie tylko suwerenność państwa wobec Kościoła, ale także nadrzędność i prawo kontroli w sprawach, które

\footnotetext{
${ }^{5}$ Maria Teresa uzasadniała swoją decyzję w następujący sposób: „Doskonałość zakonników, złączona z nią dla religii korzyść i zbawienie dusz jest główną podstawą istnienia zakonów, a pomnożenie czci i chwały Bożej jest celem świętego kościoła katolickiego. Dobre przykłady zakonników czynią chrześcijan pobożnymi, przymioty zakonników polepszają obywateli państwa, którzy przez żarliwe modły zakonników, pomnożenia się błogosławieństw bożych spodziewać mogą. Atoli do spełnienia ich powołania potrzeba prócz łaski Bożej także szczególniejszego współdziałania zakonników, gdyż powołanie ich wymaga wieczystego obumarcia, zaparcia się samego siebie i spełniania rad ewangelicznych z całą stałością, a jest ono tym cięższe, że po złożeniu ślubów staje się nieodwołalne. Każdy łatwo poznaje zatem, co za dojrzałej siły sądu - rozsądnej rozwagi i poważnego zbadania siebie potrzeba, aby nie chybić zbawiennego celu i aby nie wywołać smutnych skutków, jakie na szkodę religii i duchowieństwa towarzyszą zawsze nierozsądnie lub zbyt spiesznie zrobionemu wyborowi tego nieodwołalnego stanu. Do tak trudnego dzieła koniecznie potrzebnej przezorności nie można zaś żądać od człowieka wcześniej, jak we wieku, w którym umysł dochodzi do swej dojrzałości i przez doświadczenie nabędzie zdolności rozsądnego w rzeczach ważnych wyboru. Niedoświadczona młodzież dając się natomiast kusić nadzieją wieczystego zaopatrzenia, pozornymi wygodami i tym podobnymi zewnętrznej strony dotyczącymi okolicznościami, poddaje się zobowiązaniu dożywotniemu, a gorzki żal i przykre skutki są następnie towarzyszami ich apatycznego życia”. Dekret cesarzowej z dnia 13 września 1774, cyt. za: Bartoszewski 1893, 29.
} 
powinny być domeną władzy cywilnej. Cesarzowa oświadczyła, że chce wziąć reformę w swoje ręce, zabezpieczyć uprawnienia instytucji państwowych w stosunku do władzy duchowej i usunąć wszelkie nadużycia. Zgodnie z zasadami ewangelii zamierzała ograniczyć kler do głoszenia kazań, udzielania sakramentów i nadzorowania dyscypliny kościelnej [Góralski 1995, 200-201]. Prawo do rozdzielenia w Kościele spraw czysto kościelnych od świeckich dawało jej przekonanie, że państwu nie można było odmówić uprawnień do ingerencji tam, gdzie w grę wchodził jego spokój i dobro. Interesom państwa miały być zatem podporządkowane wszystkie dziedziny życia i instytucje, włączając w to także zakony.

\section{USTAWODAWSTWO CESARZA JÓZEFA II}

W swojej polityce wobec Kościoła katolickiego Józef II chciał bronić praw władcy absolutnego. W koncepcji prawa kościelnego wzorował się na gallikanizmie, na systemie państw protestanckich XVI w. W reformach kościelnych potępiał przepych w obrzędach religijnych, pragnął zreorganizować życie religijne i liturgię $\mathrm{w}$ duchu purystycznym, odrzucając barokowe ozdoby, usuwając obrazy, ornamenty i symbole. Był całkowitym przeciwieństwem swojej matki, która lubiła wielkie pokazy religijnej pompy i w której duszy mieszały się ze sobą bojaźń Boża i zabobon, wiara i poezja [Fejtö 1993, 232]. Józef II nie miał żadnego upodobania do pielgrzymek, procesji, kultu miejsc świętych. Zakazał nadmiernego oświetlania ołtarzy, nakazał usunąć z obrazów świętych dziwaczne stroje i wota, zabronił także kultu relikwii oraz kultu Grobu Chrystusa w czasie Wielkiego Tygodnia.

Józef II był przekonany, że zakony, które nie służą bliźniemu, nie służą też Bogu. W myśl tej zasady twierdził: „Monarchia jest zbyt uboga i zbyt zacofana, żeby mogła sobie pozwolić na zbytek utrzymywania próżniaków. Państwu potrzeba księży cnotliwych, wykształconych, którzy uczą miłości bliźniego, a nie żebrzących obdartusów i łachmaniarzy" [tamże, 233].

Sprawy zakonne w ustawodawstwie cesarza Józefa II stanowią niewielki, aczkolwiek znaczący wycinek jego aktywności w odniesieniu do życia 
kościelnego ${ }^{6}$. Możemy wymienić kilka decyzji prawnych dotyczących życia zakonnego:

1) Dekret z dnia 29 grudnia 1780 r. zabraniał nowicjuszom i profesom sub clausula nullitatis zapisywania zakonowi lub klasztorom sum pieniężnych ponad ustaloną, czyli 1500 złr (złotych reńskich). Dekret miał na celu zmniejszenie majątków zakonnych w przyszłości ${ }^{7}$.

2) Dekret z dnia 24 marca 1781 r. w sprawie wewnętrznej organizacji zakonów w Galicji. Postanowienia powyższego dekretu można zamknąć w ośmiu punktach: a) wszystkie domy zakonne położone w granicach monarchii muszą zerwać związki z klasztorami i prowincjami zagranicznymi; b) konwenty tego samego zakonu muszą być zgrupowane w jednej prowincji albo kongregacji w ciągu dwóch najbliższych miesięcy. W tym czasie

\footnotetext{
${ }^{6}$ Wśród kwestii kościelnych regulowanych zarządzeniami cesarza Józefa II można wymienić m.in: nowe prawo małżeńskie (dekret z dnia 16 stycznia 1783 r.), zakres materiału egzaminacyjnego dla proboszczów (dekret z dnia 18 lipca 1783 r.), reformy dotyczące duszpasterstwa parafialnego, jak pora i porządek sprawowanych nabożeństw (dekret z dnia 29 lutego 1783 r.), zakaz organizowania pielgrzymek trwających dłużej niż jeden dzień z wyjątkiem pielgrzymki z Wiednia do Mariazell (dekret z dnia 11 kwietnia 1782 r.), zakaz ślubów udzielanych nowożeńcom przed południem oraz pijanym nupturientom (dekret nadworny dla Galicji z dnia 28 października 1784 r.), zakaz udzielania chrztu dzieciom żydowskim bez zgody ich rodziców lub opiekunów (dekret z dnia 12 kwietnia 1787 r.), przepisy dotyczące pogrzebów (dekret z dnia 9 września 1784 r.), porządek dotyczący duszpasterstwa uczącej się młodzieży (dekret z dnia 9 października 1783 r.), zakaz przywożenia chorych do kościoła celem udzielania im sakramentu chorych (rozporządzenie z 1787 r.).

${ }^{7}$ „Ponieważ dotychczas prawie w każdej okoliczności z doświadczenia widzieć się dało, iż wielu przed złożeniem ślubów, czyli księżej professyi swoimi dobrami i majętnościami rozrządzających nowicyuszów i przyszłych professów, przeciw wyraźnemu zakazowi prawa amortyzacyi dnia 18 lutego 1775 obwieszczonego, ważyli się pod różnymi tytułami pobożnych funduszów, z oczywistym oszukiwaniem rzeczonych amortyzacyi ustaw daleko większe sumy pieniężne lub w wartości pieniężnej ad manuas mortus wyznaczać, niż im się nabywać należy, przeto słusznie umyśliliśmy niniejszym za prawo ustanowić i rozkazać, iż odtąd żaden nowicyusz czyli zakonnik, którenby przed czynieniem księżej professyi lub zakonnych ślubów testament lub inny jaki akt ultimae voluntatis czynić zamyślał, sub clausula nullitatis, nie będzie mógł mieć mocy z swojej bądź już w rzeczywistości posiadanej, bądź na potym spadającej substancyi w czymkolwiekbądź ta by się zawierała, prócz dożywocia prawami pozwolonego inaczej rozporządzać, jak tylko w rzeczonych amortyzacyi ustawach wyznaczoną dotacyą 1500 złr. wynoszące zakonowi czyli klasztorowi zapisywać i ustępować. Coby zaś snadź prócz tej sumy $1500 \mathrm{złr}$. quocunque modo ad manus mortuas jako na kościoły, fundusze, ornaty, bractwa, fundacye księże i tym podobne w takowym testamencie legowano za nieważne poczytuje się". Dekret cesarza Józefa II z dnia 29 grudnia 1780 r., cyt. za: Bartoszewski 1893, 40.
} 
sprawy różnych klasztorów muszą być określone i rozstrzygnięte $\mathrm{w}$ ten sposób, aby było wiadome, do jakiej wspólnoty zakonnej mają przynależeć; c) domy zakonne muszą zerwać wszelkie kontakty z przełożonymi generalnymi z wyjątkiem związków duchowych, aby całkowicie podlegać prowincjałom. Zakonnicy będą podporządkowani prowincjałom, a ci z kolei jurysdykcji arcybiskupów i biskupów galicyjskich; d) zakazane jest branie udziału w kapitułach zagranicznych i nawiązywanie kontaktów z „zakonnikami cudzoziemskimi”. Mogą natomiast być zwoływane kapituły krajowe, ale za zgodą władz cywilnych; e) cudzoziemiec nie może być wybrany przełożonym zakonnym w Galicji; f) porozumiewanie się z Rzymem i wyjazdy zagraniczne są zabronione; g) zakony żeńskie nie mogą być uzależnione od władz zagranicznych; h) nie wolno duchowieństwu zakonnemu sprowadzać i przywozić z zagranicy ksiąg liturgicznych i modlitewników [Gach 1984, 27].

3) Rozporządzenia z dnia 20 maja 1781 r. oraz z dnia 14 września 1782 r. dotyczyły zmniejszenia liczby zakonników. Cesarz nakazał wydalenie z klasztorów austriackich mnichów cudzoziemców. Zakazano także przez okres dziesięciu lat przyjmowania nowicjuszy. Biskupi otrzymali nakaz zwalniania zakonników ze ślubów zakonnych. Każdy klasztor miał prawo utrzymywać ściśle określoną liczbę zakonników. Klasztory utrzymujące ponad oznaczoną liczbę zakonników podlegały surowym karom [Bartoszewski 1893, 40].

4) Dekret z dnia 8 sierpnia 1781 r. o zmniejszeniu liczby duchowieństwa zakonnego. Józef II zabronił przyjmowania kandydatów do zakonu ponad ustaloną - dla każdego klasztoru - liczbę. W przypadku, gdy liczba zakonników była niewystarczająca przełożeni mogli przyjąć kandydatów do klasztoru, musieli jednak wysłać ich dane personalne władzom cywilnym i następnie oczekiwać na odpowiedź. Jeśli odpowiedź była pozytywna, kandydat mógł rozpoczynać nowicjat [Wiśniowski 1967, 340].

5) Reskrypt Nadworny z dnia 12 stycznia 1782 r. nakazał zniesienie wszystkich zakonów i klasztorów oddanych samemu tylko życiu kontemplacyjnemu. Kto nie złożył jeszcze profesji, otrzymywał jednorazową zapomogę w wysokości 150 złr. i mógł zabrać ze sobą własność wniesioną do klasztoru. Zakonnikom i zakonnicom pozwolono wyjechać za granicę, kto zaś chciał pozostać w Austrii, musiał się przenieść do innego zakonu, względnie klasztoru i otrzymywał 160 złr. rocznie [Bartoszewski 1893, 35]. 
6) Cyrkularz z dnia 13 stycznia 1782 r. stanowił, iż do każdego klasztoru winien być wyznaczony osobny komisarz „abolicyjny”, który miał przybrać sobie do spisania majątku zniesionego klasztoru dwóch urzędników buchalterii i kasowości [Chotkowski 1905, 20].

7) Dekret z dnia 16 stycznia 1782 r. przepisywał, by do akcji znoszenia klasztorów była w każdym kraju powołana osobna komisja pod przewodnictwem naczelnika kraju z powołaniem referenta kameralnego i dwóch deputowanych ze stanu prałackiego, w miejsce których w Galicji, gdzie jeszcze nie było stanów, miał gubernator zamianować dwóch kanoników [tamże, 21].

8) Dekret z dnia 18 stycznia 1782 r. nakazywał, by każdy biskup diecezjalny mianował ze swojej strony komisarza duchownego dla każdego zniesionego klasztoru [tamże].

9) Rozporządzenie $\mathrm{z}$ dnia 28 lutego 1782 r. o przeznaczeniu majątku zniesionych klasztorów stanowiło, iż cały majątek tychże miał być przeznaczony na utworzenie funduszu religijnego, z którego planowano opłacać przyznane eks-zakonnikom pensje, reszta zaś miała być przeznaczana na poparcie religii i z nią połączonych celów humanitarnych. Sprzęty kościelne po zniesionych klasztorach miały być rozdane między biedniejsze kościoły, bardziej wartościowe zaś na dobro tychże sprzedane [Bartoszewski 1893, 37].

10) Dnia 4 września 1782 r. powstała Nadworna Komisja Duchowna, wraz z jej filialnymi Komisjami w poszczególnych krajach monarchii, która miała być zwierzchnią władzą dla Kościoła w cesarstwie. Oznaczało to podjęcie przez władze państwowe procesu odrywania Kościoła partykularnego od papieża. Początkowo ograniczano, a potem likwidowano kontakty Kościoła w monarchii z papieżem. Dekretem Nadwornym z dnia 30 września 1781 r. zakazano biskupom przyjmowania jakichkolwiek poleceń z Rzymu. W ramach ograniczania życia zakonnego, a potem jego likwidacji, dekretem z dnia 11 września 1782 r. zobowiązano biskupów do znoszenia ich egzempcji oraz do współudziału w likwidacji przeznaczonych do kasat klasztorów znajdujących się na terenie diecezji [Kumor 1979, 249].

11) Rozporządzenie z dnia 3 marca $1783 \mathrm{r}$. brało w obronę podwładnych zakonników przeciw niesłusznemu prześladowaniu przełożonych. Rozporządzenie z dnia 11 marca tego samego roku nadzór nad wcześniejszymi dyrektywami powierzało komisjom składającym się $\mathrm{z}$ najdzielniejszych obywateli [tamże, 46]. 
12) Rozporządzenie $\mathrm{z}$ dnia 11 grudnia 1784 r. normowało sprawę wyboru przełożonych zakonu. Każdy klasztor miał sam wybierać przełożonych. Prowincjał miał jedynie wybór zatwierdzić. Z kolei kapituły prowincjalne miały wybierać prowincjałów na okres sześciu lat. Prowincjał miał zaniechać zwyczajnych wizytacji. Według rozporządzenia mógł wizytować klasztor tylko w przypadku wystąpienia jakichkolwiek nieporządków [tamże, 44-45] ${ }^{8}$.

13) Rozporządzeniem z dnia 1 listopada 1785 r. cesarz Józef II postanowił że żadna nowicjuszka nie może poświęcić się pracy nauczycielskiej i być dopuszczona do profesji, jeśli nie nauczy się języka niemieckiego. Była to ogólna tendencja, aby szkoły prowadzone przez pozostawione zgromadzenia uczynić narzędziem germanizacji. Ponieważ każdy klasztor żeński był zobowiązany utrzymywać szkołę, praktycznie zakonnice musiały posiadać znajomość tego języka .

14) Dekret nadworny z dnia 21 sierpnia 1786 r. dotyczył tego, aby duchowieństwo klasztorne miało wzgląd na młodych zakonników, tak by przez zbyt głośne śpiewanie w chórze nie nabywali defektów fizycznych. Cesarz Józef II zalecił, aby zaprowadzić w klasztorach umiarkowany śpiew [Bartoszewski 1893, 47].

Cesarz Józef II reformą objął całą dziedzinę życia zakonnego, zarówno zewnętrzną, jak i wewnętrzną. W tych ostatnich posuwał się do regulowania zbyt drobiazgowych kwestii, które przynależały do zakresu działań przełożonych. Celem i dążeniem Józefa II w jego rozporządzeniach, dekretach i reskryptach było odseparowanie zakonów od wpływu kurii rzymskiej, a oddanie ich pod władzę biskupów krajowych, na których rząd mógł wywierać większy wpływ. W literaturze spotykamy się z oceną Józefa II

\footnotetext{
${ }^{8}$ Wcześniej dekret z dnia 14 sierpnia 1784 r. odbierał prowincjałom prawo wizytowania klasztorów, natomiast dekret $\mathrm{z}$ dnia 30 listopada $1784 \mathrm{r}$. dawał konwentom prawo wyboru własnych przełożonych bez udziału i zgody prowincjała. Ponadto zakonnicy mieli prawo odwoływać się do biskupa, a nawet gubernatora. Od strony prawnej gubernator posiadał najwyższą władzę prawną [Chotkowski 1916, 30].

${ }^{9}$ Gubernator hr. Brigiddo podając w 1784 r. Komisji Nadwornej spis istniejących jeszcze zgromadzeń i ich majątków, jednocześnie przedstawił program nauczania w prowadzonych przez nie szkołach. Proponował, aby całe szkolnictwo żeńskie w Galicji oddać zgromadzeniom, zaś nadzór nad szkołami powierzyć świeckim wizytatorom. Postulował też, aby w każdej szkole klasztornej uczyły także osoby świeckie, zwłaszcza języka niemieckiego. Zażądał, aby do profesji dopuszczać tylko te nowicjuszki, które znają język niemiecki. Komisja Nadworna z niewielkimi zmianami zaakceptowała te propozycje [Wysocki 1979, 268].
} 
jako człowieka, dla którego ważne było dobro i szczęście swoich poddanych. W. Bartoszewski przytacza modlitwę Józefa II na łożu śmierci: „Boże! Ty jeden znasz moje serce, Ciebie też biorę na świadka, że wszystkie moje kroki i rozkazy miały wyłącznie na celu dobro i szczęście moich poddanych" [tamże, 49].

\section{OKRES MIĘDZY CESARZEM LEOPOLDEM II A KONKORDATEM Z 1855 ROKU}

Po śmierci Józefa II krótkie panowanie objął cesarz Leopold II (17901792). Rządami hołdował zapatrywaniom i reformom wprowadzonym przez swojego poprzednika. Także panowanie cesarzy Franciszka II (17921835) i Ferdynanda (1835-1848) nie pozostawiły głębszych śladów w ustawodawstwie dotyczącym zakonów w cesarstwie austriackim. Mimo iż może nie zupełnie zgadzali się oni z reformami józefińskimi, nie mieli wystarczająco sił, by zburzyć dotychczasowy porządek. Cesarz Franciszek II myślał nawet o zawarciu konkordatu ze Stolicą Apostolską, by przywrócić zakonom porządek wyznaczony przez kanony, jednak zmarł bez urzeczywistnienia swojego planu.

Wydatniejsze pod względem pozytywnych przepisów dotyczących życia klasztorów było ustawodawstwo cesarza Ferdynanda I. Należy zwrócić przede wszystkim uwagę na:

1) Dekret kancelarii nadwornej z dnia 17 października 1842 r., który uwalniał zakon jezuitów spod praw amortyzacji [tamże, 51].

2) Dekrety z dnia 9 stycznia 1843 r. i z dnia 3 marca 1848 r. normujące prawno-prywatne skutki ślubów pojedynczych [tamże].

3) Dekret z dnia 26 stycznia 1844 r. rozstrzygający zasadnicze pytanie na korzyść opieki względem zdolności małoletnich do wstąpienia do zakonu [tamże].

4) Dekret z dnia 29 lutego 1844 r. wskazujący na zasadę, że aprobowane nawet przez rząd prawo do życia według statutów zakonnych nie uwalnia zakonnika od ogólno-obywatelskich obowiązków stawania przed sądem świeckim bądź to jako świadek, bądź to jako obwiniony [tamże].

Dopiero panowanie cesarza Franciszka Józefa (1848-1916) sprawiło w dziedzinie austriackiego ustawodawstwa kościelnego, w tym także i zakonnego, dwie reakcje: jedną przeciw ustawodawstwu józefińskiemu, 
zamanifestowaną konkordatem z 1855 r., a drugą przeciw konkordatowi, zamanifestowaną w ustawach zasadniczych państwa austriackiego z $1867 \mathrm{r}$. i w ustawach majowych z 1874 r.

\section{KONKORDAT Z 18 SIERPNIA 1855 ROKU W SPRAWACH ZAKONNYCH}

Dnia 18 sierpnia 1855 r. ad certum stabilemque ordinem rerum rationumque Ecclesiae Catholicae in Imperio został zawarty konkordat między Stolicą Apostolską a cesarzem Franciszkiem Józefem. Kościół katolicki w całej monarchii miał zapewnione wszelkie prawa, jakie przysługują mu według Bożego ustanowienia i postanowień świętych kanonów. Wszelkie sprawy nieuwzględnione w konkordacie miały być rozstrzygane z poszanowaniem nauki Kościoła i według aprobowanej przez Stolicę Apostolską karności kościelnej. Cesarz zachował prawo obsadzania biskupstw i większości kanonikatów w kapitułach katedralnych, choć podkreślono, iż nominacja biskupów należy do uprawnień papieża. Ponadto konkordat zapewniał biskupom wolność korespondencji z Rzymem, zaznaczono także jurysdykcyjny prymat papieża oparty na prawie Bożym. Oznaczało to, że Kościół miał zagwarantowany wpływ na szkoły publiczne, w których wychowanie dzieci katolickich miało być całkowicie zgodne $\mathrm{z}$ jego nauką. W kompetencji sądów kościelnych pozostawiono wszystkie sprawy małżeńskie. Władza państwowa zobowiązała się potępiać poglądy przeciwne nauce Kościoła. Istotę konkordatu bardzo dobrze wyjaśnił prof. F. Słotwiński trzy lata po jego zawarciu w wykładzie naukowym opublikowanym w 1858 r. Zwrócił szczególną uwagę na artykuł pierwszy konkordatu, w którym stwierdza, że społeczność cywilna i kościelna składa się z tych samych członków oraz że panujący ma obowiązek opieki nad Kościołem katolickim i winien bronić go i przestrzegać jego postanowień ${ }^{10}$.

10 „Społeczność cywilna i kościelna z jednych i tychże samych członków złożona zostaje, ze sobą w najściślejszym związku; bo działania członków Kościoła wpływają na cel społeczności cywilnej, a działania tychże, jako członków społeczności cywilnej wpływają na osiągnienie lub utrudnienie dostąpienia celu Kościoła chrześciańskiego. Zachodzi jedynie między temi dwoma społecznościami różnica: co do ich początku, głównego i najbliższego celu, tudzież właściwych środków, jakiemi ich cele popierane i osiągnione być mogą. I tak: co do ich początku, Kościół założonym jest bezpośrednio przez Chrystusa, prawa jego opierają się na Słowie Bożem i Tradycyi, społeczność zaś cywilna 
uformowaną jest przez ludzi - jej byt prawny opiera się na tak zwanej umowie cywilnej (zjednoczenia, postanowienia co do formy rządu i poddania) wyraźnej lub dorozumianej bo $\mathrm{z}$ tej jedynie zasady, prawa najwyższej władzy rządzącej i obowiązki poddanych rozwiniętemi być mogą. Różnią się obydwie społeczności co do swego głównego i najbliższego celu - najbliższym bowiem celem Kościoła jest zbawienie prawowiernych, już zaś celem najbliższym społeczności cywilnej jest zabezpieczenie praw pierwotnych i nabytych ogółu i każdego członka społeczności. Zachodzi zaś najważniejsza różnica co do środków przez każdą z tych społeczności do osiągnienia przeznaczonego jej celu użyć się mogących; zbawienie bowiem prawowiernych nie zależy od prawości samych tylko działań zewnętrznych, ale także i od prawości działań wewnętrznych, które wymusić się nie dadzą, lecz jedynie przez nauczanie i ćwiczenia pobożne zaszczepionemi i ugruntowanemi, a wykraczający przeciw postanowieniom Kościoła nie przez kary doczesne, lecz w razie uchybienia i zaciętego uporu jedynie tylko przez zagrożenie wykluczenia z społeczeństwa kościelnego spowodowanemi być mogą. Przeciwnie cel społeczności cywilnej, to jest bezpieczeństwo wszelkich praw pierwotnych i nabytych wprost i bezpośrednio nie da się osiągnąć przez same środki działające jedynie na ulepszenie umysłu i woli - lecz tylko przez przymuszenie do legalności, to jest do zastosowania działań zewnętrznych do ustaw i wszelkich przepisów, jakich cel i dobro społeczności cywilnej wymagają. Wszakże z owego najściślejszego związku między Kościołem i społecznością cywilną zachodzącego wypływa, że ich cele i środki nie tylko sobie nie są przeciwne, ale owszem jedne wspierają drugie - bo gdzie jest bezpieczeństwo praw pierwotnych i nabytych każdemu człowiekowi służących i stosowne środki do osiągnienia tegoż celu, tam ułatwiona jest także droga do wykształcenia umysłowego i moralnego, a następnie i środki nie tylko do osiągnienia doczesnej ale i wiecznej szczęśliwości - a gdzie są podawane takie środki, tam nie tylko poszanowania wszelkich praw wrodzonych i nabytych, ale i wykonywania wszelkich cnot chrześciańskich spodziewać się należy. Mianowicie zaś spodziewać się należy tych dobroczynnych skutków od Kościoła chrześciańskiego. Tego oczywistym dowodem jest cała jego nauka nawyraźnem Słowie Bożem i Tradycyi od czasów apostolskich zagruntowana, a przez Kościół S. katolicko-apostolsko-rzymski w całości i nieskazitelności zachowana. Ona przekonywa o bytności Boga i jego najdoskonalszych przymiotach, o nieśmiertelności duszy, o nagrodach i karach w przyszłem życiu ona podaje najdzielniejsze pobudki do wszystkich cnot chrześcijańskich i do wstrętu od występków i zbrodni; ona ostrzega, że zbrodnia największą tajemnicą pokryta przed Majestatem Boskim ukrytą być nie może, że więc nawet przez samobójstwo nie może być zerwanym węzeł łączący człowieka z Wszechmocnym, Wszechwładnym i Najsprawiedliwszym Stwórcą jego. Religia nie zna rozpaczy, łagodzi wszelkie cierpienia fizyczne i moralne, pociesza w zasmuceniu, dodaje hartu duszy we wszystkich dolegliwościach. Człowiek tarczą Religii uzbrojony nie upada bynajmniej na duchu wśród najcięższego prześladowania, nie lęka się wcale śmierci, która tylko dla zbrodniarza straszną być może lecz dla tego, co wykonywa przepisy Religii chrześciańskiej jest tylko słodkiem uśnieniem, jest przejściem z kłopotów i starań doczesnych do wiecznego pokoju i nowego życia. Człowiek mający Religią jest wyższym nad potężnych nieprzyjaciół, zostaje na szczycie najwyższej godności moralnej, przed którą nawet przemoc uginać się musi; życie jego jest wiecznem, bo miłem wspomnieniem w potomności i szczęściem dla jego pokolenia, które nie może być porównanem z żadnym gatunkiem szczęścia ziemskiego, kończącem się z tem życiem, wedle Nauki Kościoła vanitas vanitatum et omnia in mundo vanitas. Mianowicie zaś zlewa Religia 
Konkordat poświęca zakonom wyłącznie jeden cały art. XXVIII, natomiast częściowo kwestie zakonne są poruszane w art. XXIX, XXX, XXXIV, XXXV. Zatem w art. XXVIII jest mowa o tym, że zakonnicy podlegają władzy swoich przełożonych generalnych, którzy mieli także zagwarantowaną swobodę komunikowania się ze Stolicą Apostolską. Zakonnicy bez przeszkód mieli zachowywać reguły swojego instytutu, kongregacji i według przepisów Stolicy Apostolskiej kandydaci mogli być dopuszczani do nowicjatu oraz składania ślubów zakonnych. Przepisy powyższego artykułu konkordatu miały się odnosić również do zakonów żeńskich. W art. XXVIII czytamy: „Zakonnicy poddani na podstawie ustaw swego zakonu generalnym przełożonym, przebywającym przy Stolicy Świętej, podlegają ich zarządowi wedle pomienionych ustaw, nie uwłaczając wszakże powadze biskupiej, opartej na prawie kanonicznym, a w szczególności na uchwałach Soboru Trydenckiego. Pomienieni przełożeni generalni komunikować się będą swobodnie ze swymi poddanymi we wszystkich do ich urzędu należących sprawach i dowolnie wizytacje u nich odbywać. Dalej będą zachowywać zakonnicy bez żadnej przeszkody reguły swego zakonu, instytutu lub kongregacji i wedle przepisów Stolicy Świętej dopuszczać kandydatów do nowicjatu i do składania ślubów zakonnych. Toż samo ma być zachowane także co do zakonów kobiecych o ile do nich da się zastosować. Arcybiskupom i biskupom wolno będzie zaprowadzać we własnych diecezjach zakony lub kongregacje religijne płci obojga - wedle świętych przepisów kanonicznych, porozumieją się jednak w tej kwestii z rządem cesarskim"11.

chrześciańska błogie swe skutki w społeczności cywilnej, zalecając posłuszeństwo nie tylko Władzy duchownej ale zarazem i Świeckiej, nakazując oddawać Cesarzowi, co jest Cesarskiego, a to co jest Boskiego, Bogu; ona nakazuje cześć należną Panującym ziemskim w stopniu najwyższym w słowach wyrzeczonych przez Pawła Apostoła do naczelnego rządcy w Jerozolimie: «Ad tribunal Caesaris sto, ibi me oportet iudicari» «Caesarem appello» ona łączy wszystkich ludzi bez różnicy ich wyznania węzłem braterskiej chrześciańskiej miłości i wzajemnej pomocy, ona więc jest kamieniem węgielnym bezpieczeństwa, spokojności i pomyślności Narodów. A tak widocznie pokazuje się, że takiej instytucyi żadna władza ludzka; lecz jedynie Kościół chrześciański na opoce Piotra S. przez Chrystusa oparty zastąpić może. Możnaż przeto powątpiewać o tej prawdzie, że każdemu Panującemu służy prawo nie tylko najwyższej nad Kościołem chrześciańskim widzialnym opieki, ale nawet obrony przez odpowiednie i stosowne środki, zniewalające każdego do zachowania w całości najświętszych Kościoła katolicko-apostolsko-rzymskiego postanowień" [Słotwiński 1858, 1-4].

11 „Jene Ordenspersonen, welche laut den Satzungen ihres Ordens Generalobern, die bei dem hl. Stuhl ihren Wohnsitz haben, unterstehen, werden vondenselben Gemässheit der gedachten Satzungen geleitet werden, jedoch ohne Beeinträchtigung der Rechte, 
Pozostałe - wymienione wyżej - cztery artykuły konkordatu pośrednio dotyczą spraw zakonnych:

Art. XXIX: „Kościół będzie uprawniony w sposób prawny nabywać dowolnie nowe posiadłości, a własność jego pozostaje we wszystkim co teraz posiada i na przyszłość nabędzie uroczyście nienaruszalną"12.

Art. XXX: „Zarząd dóbr kościelnych prowadzić będą ci, którzy do tego wedle prawa kanonicznego są powołani"13.

Art. XXXIV: „Inne sprawy dotyczące osób i rzeczy kościelnych, o których w tych artykułach żadnej nie uczyniono wzmianki, będą we wszystkim prowadzone i zarządzane wedle nauki Kościoła i zatwierdzonej przez Stolicę Świętą karności”"14.

Art. XXXV: „Wszystkie w cesarstwie austriackim i pojedynczych dzielnicach, z których się ono składa, wydane dotąd ustawy, rozporządzenia i dekrety, mają być uważane za zniesione tą uroczystą umową o ile jej się sprzeciwiają, sama zaś umowa ma mieć odtąd na wieczne czasy we wszystkich dzielnicach moc prawa państwowego. Obie strony zawierające umowę przyrzekają zatem, że tak one, jak też ich następcy zachowają wszystko w ogólności i każdą rzecz w szczególności, na którą się zgodzono. Gdyby jednak później powstać miała jakaś trudność - Jego Świątobliwość i Jego

welche nach Bestimmung der Kirchengesetze und insbesndere des Concils von Trient den Sischöfen zukommen. Daher werden vorbenannte Generalobern mit ihren Untergebenen in allen zu ihrem Amt gehörigen Dingen frei verkehrer und die Visitation derselben frei vornehmen. Ferner werden alle Ordenspersonen ohne Hinderniss die Regel des Ordens, des Instituts, der Congregation, welcher sie angehören, beobachten und in Gemässheit der Vorschriften des hl. Stuhls die darum Ansuchenden in`s Noviciat und zur Gelübdeablegung zulassen. Dieses Alles hat auch von den weiblischen Orden in so weit zu gelten, als es auf dieselben Anwendung leidet. Den Erzbischöfen wird es frei stehen in ihren Diöcesen geistliche Orden und Congregationen beiderlei Geschlechts nach den heil Kirchengesetzen einzuführen. Doch werden sie sich hierüber mit der kaiserlichen Regirung in`s Ein vernehmen setzen” [Buss 1862, 306-308].

12 „Die Kirche wird berechtig sein, neue Besitzungen auf jede gesetzliche Weise frei zu erwerben und ihr Eingenthum wird hinsichtlich alles dessen, was sie gegenwärtig besitzen order in Zukunft erwirbt, umverletzlich bleiben” [tamże, 318-19].

13 „Die Verwaltung der Kirchngüter wird von denjenigen geführt werden, welchen sie nach den Kirchengesetzen obliegt” [tamże, 319].

${ }_{14}$ „Das übrige die kirchlichen Personen und Sachen Betreffende, wovon in diesen Artikeln keine Meldung genacht ist, wird sämmtlich nach der Lehre der Kirche und ihrer in Kraft stehendenvon dem hl. Stuhl gut geheissenen Disciplin geleitet und verwalten werden" [tamże, 326-27]. 
cesarska Mość naradzą się nawzajem celem przyjacielskiego załatwienia tej sprawy"15.

\section{PODSUMOWANIE}

Przez prawie dwadzieścia lat w sprawach dotyczących zakonów w Austrii obowiązywały przepisy wprowadzonego konkordatem z 1855 r. powszechnego prawa kanonicznego. Dopiero ustawa z dnia 7 maja 1874 r. znosząca konkordat i nie pozostawiająca w jego miejsce żadnych przepisów dotyczących zakonów wprowadziła chaos i zamieszanie. Aby stwierdzić, czy jakiś przepis józefiński obowiązuje, trzeba było przejść przez gąszcz przepisów XIX w. i zastanawiać się, czy i co stanowił w tych kwestiach przepis Leopolda, Franciszka, Ferdynanda i czy konkordat zniósł go czy nie, a następnie czy ustawa znosząca konkordat restytuowała tym samym poprzednio obowiązujący przepis, czy też nie.

\section{PIŚMIENNICTWO}

Bartoszewski, Witołd. 1893. O zakonach wedle austryjackiego prawa kościelnego $i$ kanonicznego. Lwów: Nakładem Księgarni H. Altenberga z Drukarni Polskiej.

Bruździński, Andrzej. 2014. „Kasaty klasztorów męskich w Krakowie na przełomie XVIII i XIX w.” W Kasaty klasztorów na obszarze dawnej Rzeczypospolitej Obojga Narodów i na Ślasku na tle procesów sekularyzacyjnych w Europie. T. 1: Geneza. Kasaty na ziemiach zaboru austriackiego i rosyjskiego, red. Marek Derwich, 141-58. Wrocław: Wrocławskie Towarzystwo Miłośników Historii. Oddział Polskiego Towarzystwa Historycznego.

Buss, Franz J. 1862. Österreich's Umbau im Verhältnis des Reichs zur Kirche. Erste Abtheilung. Das Concordat. Wien: Braumüller.

15 „Alle im Kaiserthum Oesterreich und den einzelnen Ländern, aus welchen dasselb besteht, bis gegenwärtig in was immer für einer Weise und Gestalt erlassenen Gesetze, Anordnungen und Verfügungen sind, insoweit sie diesem feierlichen Vertrag wiederstehen, für durch denselben aufgehaben anzusehen. Dieser Vertrag selbst wird in denselben Ländern von nun an immerdar die Geltung eines Staatsgesetzes haben. Desshalb verheissen beide vertragschliessenden Theil, dass Sie und Ihre Nachfolger Alles und Jedes worüber man sich vereinbart hat, gewissenhaft beobachten werden, Wofern sich aber in Zukunft eine Schwerigkeit ergeben sollte, werden Seine Heiligkeit und Seine kaiserliche Majestät sich zur freudschaftlicher Beilegung der Sache ins Einvernehmen setzen" [tamże, 327-29]. 
Chotkowski, Władysław. 1905. Historya polityczna dawnych klasztorów panieńskich $w$ Galicyi 1773-1848 na podstawie akt cesarskiej kancelaryi nadwornej. Kraków: Gebethner.

Chotkowski, Władysław. 1909. Historya polityczna Kościoła w Galicyi za rzq̨ów Maryi Teresy. T. 1. Kraków: G. Gebethner i Sp. z zasiłkiem Akademii Umiejętności.

Chotkowski, Władysław. 1916. „Dzieje klasztorów i monasterów galicyjskich w czasach rozbiorowych. Cz. I: Zakony doszczętnie zniesione.” Sprawozdania z czynności i posiedzeń PAU 16, nr 6:26-40.

Fejtö, François. 1993. Józef II. Habsburg rewolucjonista. Warszawa: Państwowy Instytut Wydawniczy.

Gach, Piotr P. 1984. Kasaty zakonów za ziemiach dawnej Rzeczypospolitej i Ślaska 1773-1914. Lublin: Redakcja Wydawnictw KUL.

Góralski, Zbigniew. 1995. Maria Teresa. Wrocław: Zakład Narodowy im. Ossolińskich.

Krętosz, Józef. 1996. „Józefiński proces budowy Kościoła państwowego na terenie monarchii Habsburskiej w okresie rządów cesarza Józefa II (1780-1790).” Śląskie Studia Historyczno-Teologiczne 29:41-67.

Kumor, Bolesław. 1979. „Ustrój Kościoła katolickiego w zaborze austriackim (17721815).” W Historia Kościoła w Polsce. T. 2: 1764-1945. Cz. I: 1764-1918, red. Bolesław Kumor, i Zdzisław Obertyński, 277-87. Poznań-Warszawa: Pallottinum.

Słotwiński, Feliks. 1858. Wykład naukowy konkordatu między Jego Światobliwościa Piusem IX i jego ces. król. apostolska mościa Najjaśniejszym Franciszkiem Józefem I cesarzem Austryi. Dnia 18 sierpnia 1855 e. $w$ Wiedniu zawartego, a dnia 25 wrzesnia t. r. ratyfikowanego, przez Patent Cesarski dnia 5. listopada t. r. w całej Monarchii Austryackiej jako Prawo Stanu ogłoszonego. Kraków: Druk. C. K. Uniwersytetu Jagiellońskiego.

Wiśniowski, Gregoire. 1967. „Histoire de la Province de «Małopolska» ou Polonia Minor des Franciscains Reformes dans les annes 1771-1810.” Archivum Franciscanum Historicum 60, nr 3-4:325-83.

Wysocki, Jan. 1979. „Kościół katolicki w zaborze austriackim w latach 1772-1815.” W Historia Kościoła $w$ Polsce. T. 2: 1764-1945. Cz. I: 1764-1918, red. Bolesław Kumor, i Zdzisław Obertyński, 235-77. Poznań-Warszawa: Pallottinum.

\section{Przepisy austriackiego prawa kościelnego w sprawach zakonnych od czasów cesarzowej Marii Teresy do konkordatu z 1855 roku}

\section{Streszczenie}

Jednym z dążeń józefinizmu było utworzenie autonomicznego Kościoła narodowego, połączonego z Rzymem. W realizację tego zadania wpisywał się nurt „antyzakonny” w polityce kościelnej Austrii. Celem artykułu jest przedstawienie ustawodawstwa austriackiego (w omawianym okresie) dotyczącego kwestii zakonnych. Należy pamiętać, że są to przepisy wydane przez panujących cesarzy, a nie instrukcje, komentarze, zalecenia wydawane przez Gubernium we Lwowie. Na szczególną uwagę zasługują przepisy Marii Teresy oraz Józefa II. Pierwsza podkreślała nie tylko suwerenność państwa wobec Kościoła, ale także nadrzędność i prawo kontroli w sprawach, które powinny być domeną władzy cywilnej. Interesom państwa miały być podporządkowane wszystkie dziedziny życia i instytucje, włączając w to również zakony. Z kolei Józef II swoją 
reformą objął całą dziedzinę życia zakonnego, także tę wewnętrzną, gdzie posuwał się do regulowania zbyt drobiazgowych kwestii. W swoich przepisach chciał odseparować zakony od wpływu kurii rzymskiej, a oddać je pod władzę biskupów krajowych, na których rząd mógł wywierać większy wpływ.

Słowa kluczowe: Austria; austriackie ustawodawstwo kościelne; cesarz Józef II; zakony; kasaty klasztorne

\section{The Provisions of Austrian Ecclesiastical Law on Religious Matters from the Time of Empress Maria Theresa to the 1855 Concordat}

\section{Summary}

One of the aspirations of Josephinism was to establish an autonomous national church, united with Rome. The "anti-monastic" trend in ecclesiastical politics in Austria has been part of fulfilling this task. The aim of the article is to set out the Austrian legislation (in this respect) concerning religious matters. It should be kept in mind that these are regulations issued by reigning emperors, not instructions, comments, recommendations issued by the Lviv Governium. Particularly noteworthy are the provisions of Maria Theresa and Joseph II. The former highlighted not only the sovereignty of the state over the Church, but also the supremacy and right of control of the Church in matters that should be the domain of civil authority. State interests were to be subordinated to all areas of life and institutions, including the religious. On the other hand, Joseph II, with his reform, covered the entire field of religious life, including the internal one, where he set about regulating too detailed issues. In his regulations, he wanted to separate orders from the influence of the Roman Curia, and to place them under the authority of national bishops over whom the government could exert more influence.

Key words: Austria; Austrian ecclesiastical legislation; Emperor Joseph II; monasteries; dissolution of the monastery

Information about Author: Rev. Robert Kantor, HAB. PH.D. - Department of Practical Theology and Canon Law, the Theological Faculty, Branch in Tarnów of the Pontifical University of John Paul II in Kraków; e-mail: kanclerz@diecezja.tarnow.pl; https://orcid.org/0000-0002-8599-7705 